\title{
PROTOPARMELIA HYPOTREMELLA, A NEW STERILE CORTICOLOUS SPECIES FROM EUROPE, AND ITS LICHENICOLOUS FUNGI
}

\author{
A. APTROOT ${ }^{\star}$, P. DIEDERICH $\ddagger$, C. M. VAN HERK $\mathbb{S}$, L. SPIERף \\ and $\mathrm{V}$. WIRTH
}

\begin{abstract}
Protoparmelia hypotremella van Herk, Spier \& Wirth, a sterile corticolous lichen, is described as a species new to science, so far known from Austria, SW Germany and the Netherlands. It is rapidly spreading in Germany and the Netherlands. It is apparently close to $P$. oleagina, and is often found growing together with that species on oak trees along roads in the Netherlands. Both species are host to the lichenicolous fungi Sphinctrina anglica and Tremella wirthii.
\end{abstract}

C) 1997 The British Lichen Society

\section{Introduction}

The corticolous lichen flora of roadside trees in western Europe is among the best known lichen floras in the world. Mainly due to environmental stress (air pollution with sulphur dioxide), the composition of this flora has changed drastically during this century. After a steady decrease in biodiversity until the seventies, in recent decades a rapid increase in species diversity has been observed in formerly polluted areas, due to significantly falling levels of sulphur dioxide (van Herk 1993). Those lichens now on the increase are mainly the same species that had decreased. There are, however, a few remarkable exceptions. Among these are two corticolous species of Protoparmelia, viz. P. oleagina (Harm.) Coppins and the new species $P$. hypotremella (Fig. 1), which is described below.

Both Protoparmelia species are spreading rapidly on old roadside trees in the Netherlands, especially on Quercus robur, where the new species is now known from more than 100 localities. In the Netherlands both species of Protoparmelia are known only in a sterile condition. Since 1988 the new species has been repeatedly found by the last author in SW Germany on Quercus, Fagus and Pinus sylvestris. Finally, it was found by the third author during an excursion in lowland Austria, organized by Dr F. Berger (Kopfing) during the IAL. congress at Salzburg in 1996, this time on Fagus. It was also recently collected in Austria at higher altitudes, up to $1670 \mathrm{~m}$, on Larix decidua and on wood.

Protoparmelia oleagina has recently been reported from the Netherlands (van Herk 1993). The identity was confirmed by comparing the Dutch specimens

*Centraalbureau voor Schimmelcultures, P.O. Box 273, NL-3740 AG Baarn, The Netherlands. $\Varangle$ Musée national d'histoire naturelle, rue Münster, L-2160 Luxembourg, Luxembourg.

SLichenologisch Onderzoekbureau Nederland, Goudvink 47, NL-3766 WK Soest, The Netherlands.

『Koning Arthurpad 8, NL-3813 HD Amersfoort, The Netherlands.

Staatliches Museum für Naturkunde, Rosenstein 1, D-70191 Stuttgart, Germany. 
(Fig. 2) with fertile British material. In our opinion the species is correctly placed in Protoparmelia. It represents one of the few corticolous species known in the genus.

The new species of Protoparmelia had been incorrectly called Hypocenomyce caradocensis (Leight. ex Nyl.) P. James \& G. Schneider in the Dutch literature (Brand et al. 1988), as both species are rather similar in appearance (Fig. 3). The oldest record of $P$. hypotremella in the Netherlands probably dates from 1972 as a field record called 'Toninia caradocensis' during a mapping programme. At the same locality $P$. hypotremella is still present. Both in Germany and in the Netherlands the species is known to grow on trees from which it was definitely absent 5 years earlier. In 900 sample plots of mainly wayside trees in the Netherlands the number of records increased from 15 in 1989 to 29 in 1994, thus nearly a $100 \%$ increase in 5 years. It is remarkable that the new species is not known from Great Britain, whereas P. oleagina is known there, but with a different habitat preference, being more common on wooden fences and in native pine forest.

As all known old records of $P$. hypotremella are from mountain areas in central Europe, this region probably comprises the original, 'natural ' habitat, from which it has recently started to spread over lowland western Europe. A similar phenomenon has been observed with Chaenotheca ferruginea (Turner ex Ach.) Mig., Cyphelium inquinans (Sm.) Trevis., Hypocenomyce sorophora (Vain.) P. James \& Poelt, Lecanora conizaeoides Nyl. ex Crombie, Mycoblastus fucatus (Stirt.) Zahlbr and Parmeliopsis ambigua (Wulfen) Nyl. (Wirth 1985).

\section{Materials and Methods}

All specimens of the new species in the herbaria ABL (hb. Aptroot), STU, hb. van Herk (Soest) and hb. Spier (Amersfoort) have been examined. The Austrian, German and Dutch specimens of $P$. hypotremella and $P$. oleagina have also been checked for lichenicolous fungi. Fertile British material of $P$. oleagina was borrowed from $\mathrm{E}$. The chemistry of both $P$. hypotremella and $P$. oleagina has been checked by HPLC using collections from the type locality of $P$. hypotremella. Some additional specimens have been tested by TLC.

\section{The species}

Although the new species is not known to produce apothecia, we describe it here in Protoparmelia for the following reasons:

1. The cortical and internal structures (including the photobiont) match other Protoparmelia species, especially $P$. oleagina.

2. Both $P$. oleagina and the new species host Sphinctrina anglica and Tremella wirthii (see below).

3. The chemistry fits Protoparmelia and is in fact identical to that of P. oleagina.

\section{Protoparmelia hypotremella van Herk, Spier \& Wirth sp. nov.}

Species corticola. Thallus sterilis, griseus vel olivaceus, granulatus ad microsquamulosus, corticatus. Squamae ad $0 \cdot 2(-0 \cdot 6) \mathrm{mm}$ latae, ad $0.1 \mathrm{~mm}$ altae, cum marginibus pallidioribus, 
acidum lobaricum continentes; prothallo deficiente. Epicortex 5-10 $\mu \mathrm{m}$ altus; cortex paraplectenchymaticus, $15-25 \mu \mathrm{m}$ altus, cellulis $6-9 \mu \mathrm{m}$ diam; medulla $60-150 \mu \mathrm{m}$ alta; algas chlorococcoideas, $6-12 \mu \mathrm{m}$ diam, in parte superiore continens. Habitus cum Protoparmelia oleagina et Hypocenomyci caradocensis congruens.

Typus: The Netherlands, Friesland, Oldeberkoop, on Quercus robur along Oosterwoldse Weg, alt. 2 m, 30 October 1996, C. M. van Herk 2493-5 (B-holotypus; ABL, B, E, STU, hb. Diederich, hb. van Herk, hb. Spier-isotypi; TLC!).

(Figs 1, 4, 5)

Thallus corticolous, indeterminate, covering areas of up to several square decimetres, grey to pale olivaceous to buff, paler along the margins of the granules, dull to slightly glossy, consisting of squamulose granules, corticate, without prothallus, without discernible thallus below or around the granules. Granules partly isidia-like, convex, rounded to elongate or globose, c. $0.1 \mathrm{~mm}$ high, c. $0.2 \mathrm{~mm}$ wide, partly microsquamulose and crenate to lobate, convex to flat or slightly concave, gnarled, up to $0.3 \mathrm{~mm}$ high, up to $0.6 \mathrm{~mm}$ wide. Microsquamules sometimes bearing isidia-like granules, which are relatively dark-tipped, but furthermore identical to the regular isidia-like granules. Margins of the granules often eroding and less corticate, often whitish, always paler than the surface. The squamulose granules randomly occur amongst the isidia-like granules, not predominantly along the margins of the thallus. Internal structure: Epicortex 5-10 $\mu \mathrm{m}$ thick, hyaline; cortex 15-25 $\mu \mathrm{m}$ thick, pale brownish due to pigments, paraplectenchymatous, with lumina $c .6-9 \mu \mathrm{m}$ wide; medulla 60-150 $\mu \mathrm{m}$ thick, rather loose, hyphal, with filaments $c$. 3-5 $\mu \mathrm{m}$ wide, walls partly incrusted with crystals (lobaric acid?); upper layer of the medulla filled with chlorococcoid algae of $c$. 6-12 $\mu \mathrm{m}$ diam.

Ascomata and conidiomata unknown.

Chemistry: Lobaric acid (major, determined by HPLC), \pm unknowns (minor); spot reactions in medulla and cortex $\mathrm{C}-$ or \pm yellow, $\mathrm{K}-, \mathrm{KC}-$ or + pink, PD - , UV + + white.

Etymology: From hypo, under, and Tremella referring to the occasional presence of the lichenicolous fungus Tremella wirthii, and at the same time reminiscent of Hypocenomyce caradocensis.

Ecology and distribution: The Netherlands: Mainly on old wayside Quercus robur trees, occasionally on $Q$. rubra. It prefers sun-exposed, more or less wind-sheltered sites with a slightly to moderately eutrophicated, usually dusty, rough bark. Mean bark $\mathrm{pH}: 5 \cdot 15$ (3 records). It occurs in species-rich communities (mean number of lichens per site of ten trees: 26), often accompanied by Buellia griseovirens (Turner \& Borrer ex Sm.) Almb., Ochrolechia androgyna (Hoffm.) Arnold, Pertusaria coccodes (Ach.) Nyl., Pyrrhospora quernea (Dicks.) Körb. and Protoparmelia oleagina (Table 1). It is common in most areas with a relatively low sulphur dioxide level and old Quercus trees, except in the coastal dune area. Only a few records are known from the southern part of the country, with higher sulphur dioxide levels. All records are from areas below $100 \mathrm{~m}$ alt. Germany: More than ten records, mostly in Baden-Württemberg, on Fagus, Pinus sylvestris and Quercus trees in generally slightly more sheltered places, both in lowland and upland (c. $500-1000 \mathrm{~m}$ ) regions. The recent localities are only slightly polluted by 

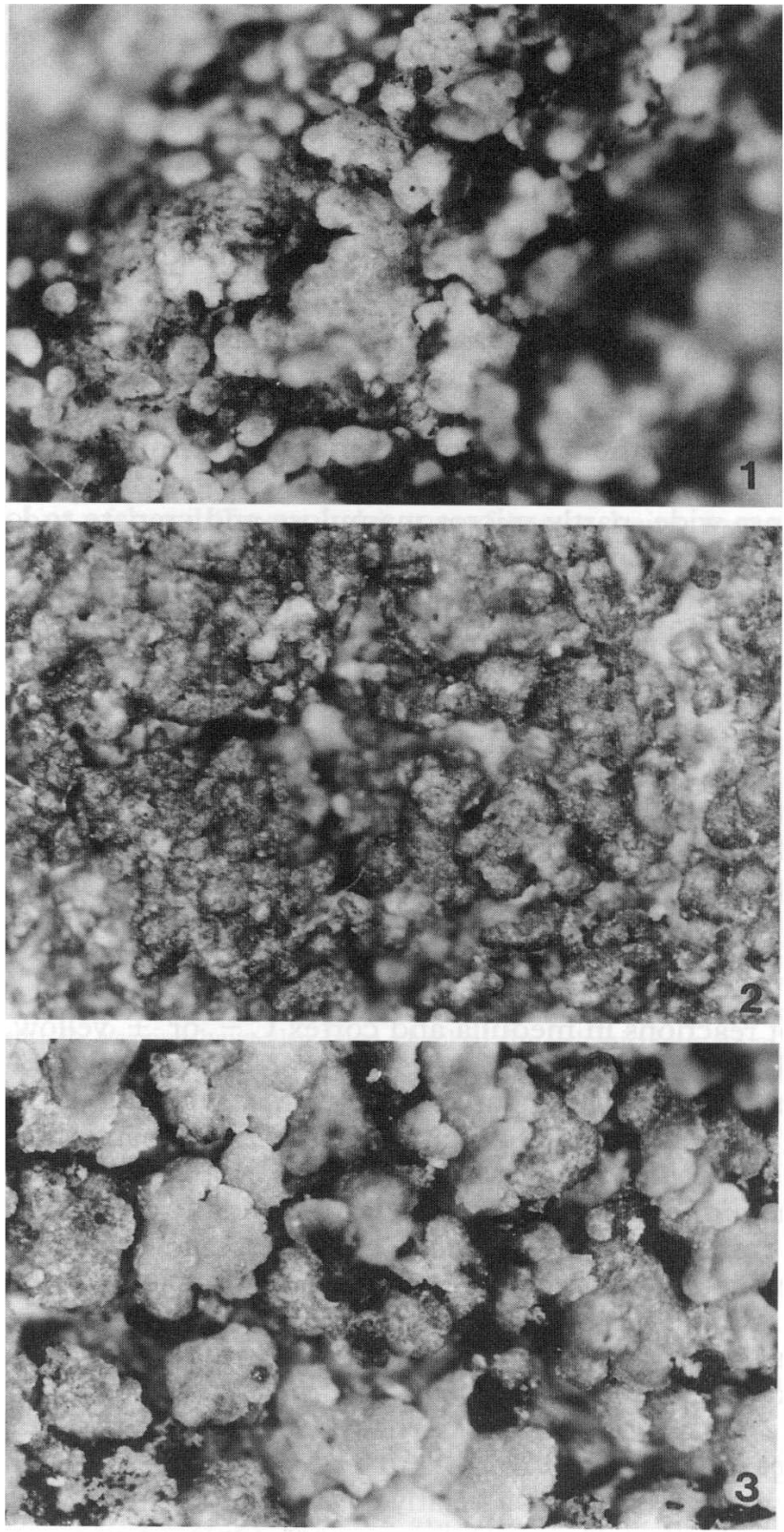

\section{$1 \mathrm{~mm}$}

Figs 1-3 Habitus photographs. Fig. 1. Protoparmelia hypotremella (type). Fig. 2. Protoparmelia oleagina (from the type locality of $P$. hypotremella). Fig. 3. Hypocenomyce caradocensis (Austria Aptroot 39932). 


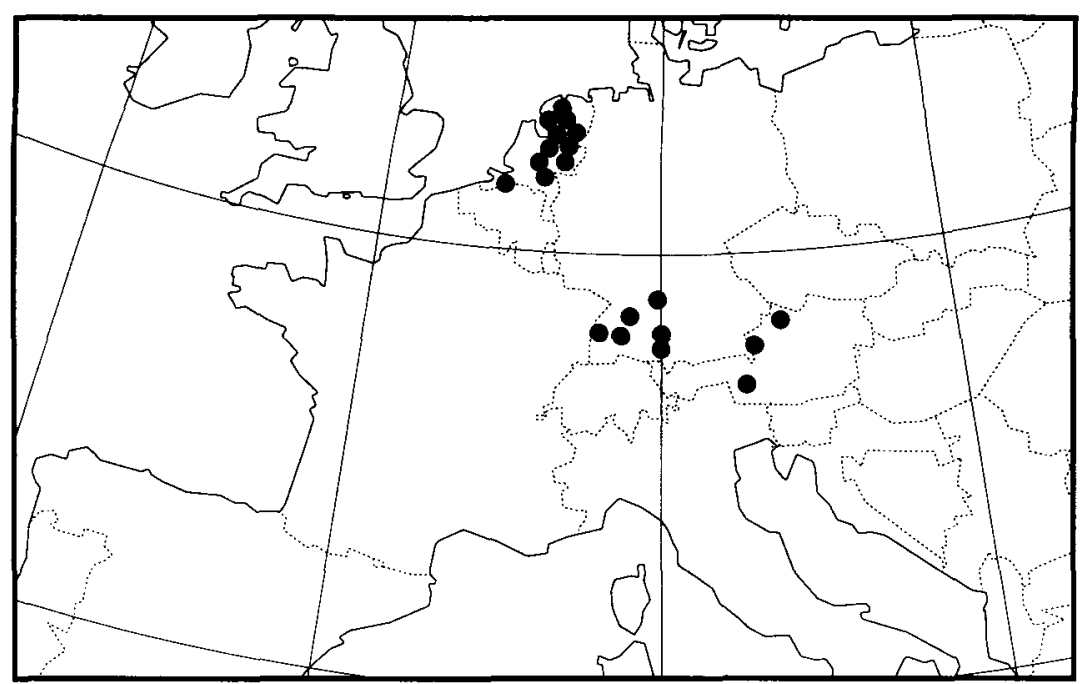

FIG. 4. Known distribution of Protoparmelia hypotremella. The species may well be present in areas adjacent to those indicated, where no recent surveys have been carried out.

sulphur dioxide, but the trees are mostly poor in species, with one exception, where both lichenicolous fungi were present, together with for example Agonimia tristicula (Nyl.) Zahlbr., Parmelia pastillifera (Harm.) R. Schubert \& Klem. and Phaeophyscia endophoenicea (Harm.) Moberg. Austria: Known from very different habitats, including old, eutrophicated Fagus trees in a wood along the Donau at lower altitude $(400 \mathrm{~m})$ and Larix decidua in the higher $(1670 \mathrm{~m})$ Alps.

Discussion: The new species resembles Protoparmelia oleagina (Fig. 2), with which it shares the internal structure, the alga, the characteristic, dull to slightly glossy surface and the presence of lobaric acid. However, the thallus of $P$. oleagina is continuous and its isidia-like structures are only outgrowths of it. The thallus is therefore more delimited. The isidia are consistently smaller (c. $0.1 \mathrm{~mm}$ diam.) and the thallus colour is much darker (grey to olivaceous brown or black), without paler margins to the 'granules'. The difference in colour is not due to environmental effects, as can be observed when both species grow side by side, which happens rather often (Table 1). At these localities both species behave as distinct entities. The major chemical compound of $P$. hypotremella, lobaric acid, was found to be present in $P$. oleagina as well. This represents the first report of lobaric acid in the latter species, for which only some unknown substances were reported before (Coppins 1992). Lobaric acid is common in the genus. Protoparmelia oleagina does not show the positive UV-reaction of $P$. hypotremella. In microscopical preparations a $\mathrm{K}+$ oily substance reaction can be observed in $P$. oleagina and $P$. montagnei (Fr.) Poelt \& Nimis, but not in $P$. hypotremella.

The new species could be mistaken for Hypocenomyce caradocensis (Fig. 3), with which it shares the microsquamules, but not the gnarled isidia-like 


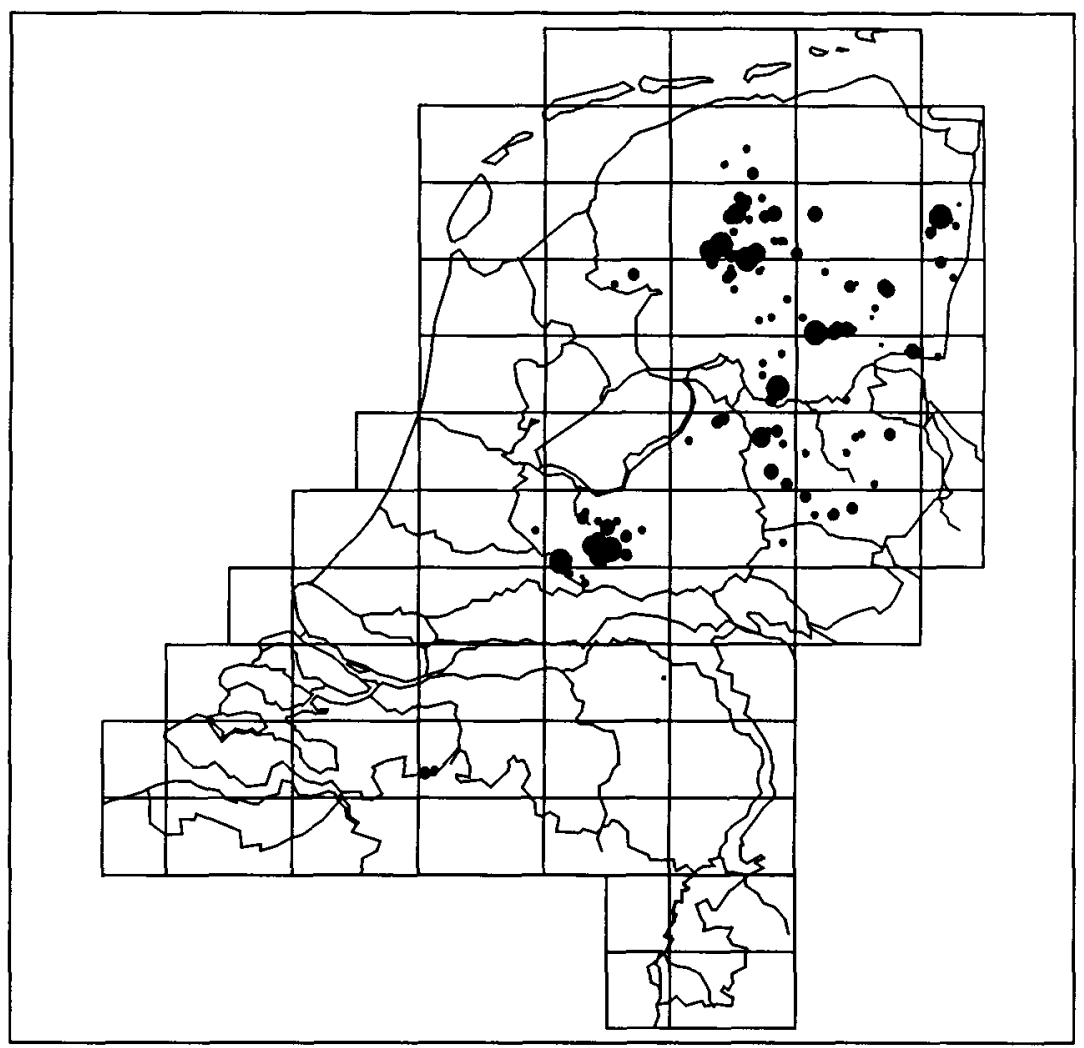

Fig. 5. Distribution of Protoparmelia hypotremella in the Netherlands, based upon herbarium specimens and field records. Small dots indicate single specimens, large dots places with abundant growth (more than $1 \mathrm{dm}^{2}$ per tree). The field records are based on a mapping programme of 6000 localities with ten Quercus robur trees, carried out between 1989 and 1995 by the third author.

structures. The chemistry is different: $H$. caradocensis is sometimes UV + white, but this is due to unknown substances, not to lobaric acid. The internal structure is also different as $H$. caradocensis has periclinally oriented hyphae in the cortex, the surface is dull to almost felty, and it often has a frosty appearance. Moreover, the microsquamules in $H$. caradocensis tend to be more divided and often overlapping; they remain convex and become larger (up to $1 \mathrm{~mm}$ ).

Finally, the grey isidia-like granules are reminiscent of sterile specimens of Bacidia rubella (Hoffm.) A. Massal., which differ in the fairly uniform, pale grey to greenish grey colour and in the different chemistry (no substances, $\mathrm{UV}-$ ).

Selected specimens (see Fig. 4): Austria: Oberösterreich: Steinerfelsen near Schlögener Schlinge along the Donau, halfway between Linz and Passau, alt. $540 \mathrm{~m}$, on Fagus, 4 ix 1996, C. M. van Herk s.n. (hb. van Herk, with Tremella wirthin), A. Aptroot 39902 (ABL, with Tremella wirthir), F. Berger 10160 (hb. Berger, hb. Diederich, with Tremella wirthit). Osttirol: Hohe Tauern, 
Glocknergruppe, Dorfertal, alt. $1670 \mathrm{~m}$, on Larix decidua, with Sphinctrina anglica, 6 ix 1990, R. Türk (STU); Virgen, Zedlach, alt. $1600 \mathrm{~m}$, on wood, with Sphinctrina anglica, 2 viii 1988, R. Türk, distributed in Vèzda, Lich. sel. exs. no 2281 (B).-Germany: Bayern: Neu-Ulm, Holzheim, Steinheim, 6 ii 1991, V. Wirth 21713 (STU, with Tremella wirthii). Württemberg: Neckar, Leonberg, Warmbronn, on Quercus, 28x1988, V. Wirth 17412 (STU, with Tremella wirthit); Schwäbische Alb, Dotternhausen, Plettenberg, $1000 \mathrm{~m}$, on Pinus sylvestris, $28 \times 1993$, V. Wirth 25272 (STU); Baden: Schwarzwald, Lahr, $520 \mathrm{~m}$, on Quercus, 9 viii 1988, V. Wirth 16992 (STU, with Sphinctrina anglica).-The Netherlands (see fig. 5): (all below $100 \mathrm{~m}$ alt.) Friesland: Type. Drenthe: Havelte, Nijeveense Bovenboer, on Quercus along road, 8 ix 1985, A. Aptroot 15791 (ABL); Hoogeveen, Noordsche Schut, on Quercus along road, 5 vii 1991, C. M. van Herk 2233-10 (hb. van Herk, with Sphinctrina anglica). Overijssel: Tubbergen, on Quercus, along road, 1 vi 1989, C. M. van Herk 234 (hb. van Herk). Gelderland: Hoevelaken, on Quercus, 5 iv 1991, L. Spier 2302 (hb. Spier, with Tremella wirthin); same locality, 1 ii 1993, L. Spier 4391 (hb. Spier, TLC!). Utrecht: Leusden, on Quercus along road, 3 xii 1993, C. M. van Herk 4017 (hb. van Herk, with Sphinctrina anglica); same locality, 11 iii 1996, A. Aptroot 39082 (ABL), B. F. Coppins s.n. (E); same locality, 2 vi 1991, L. Spier 2468 (hb. Spier, TLC!); Renswoude, on Quercus along road, 27 i 1984, W. O. van der Knaap s.n. (ABL); Hooglanderveen, on Quercus in wood, 27 iii 1991, L. Spier 2306 (hb. Spier, with Sphinctrina anglica, TLC!). Noord-Brabant: Wernhout, on Quercus along road, 5 viii 1993, C. M. van Herk 3492-9 (hb. van Herk).

\section{Lichenicolous fungi}

Two species of lichenicolous fungi have been found on both Protoparmelia oleagina and on P. hypotremella:

Tremella wirthii Diederich has been observed on most of the German, on a single Austrian, and on two Dutch specimens of $P$. hypotremella. In the type locality of $P$. hypotremella, it grows on $P$. hypotremella and on $P$. oleagina.

Sphinctrina anglica Nyl. has been observed on British and Dutch material of P. oleagina (Coppins 1992; Spier \& van Herk 1993), and on Austrian, Dutch (Spier \& van Herk 1993) and German material of $P$. hypotremella. Older records of $S$. anglica have often been published as growing on unidentified lichen thalli. As both Protoparmelia species are poorly known by lichenologists and are mostly sterile, is it conceivable that some of these literature records are also on Protoparmelia.

The lichenicolous species of Tremella, and probably also the species of Sphinctrina are highly specialized fungi, each of them restricted to a small monophyletic group of lichens. The existence of two lichenicolous species, known only on $P$. oleagina and on $P$. hypotremella, is a strong argument to consider both lichen species as closely related.

Specimens examined: Tremella wirthii (the specimens mentioned by Diederich 1996: 164-166 are not repeated here). Austria: Oberösterreich: Steinerfelsen near Schlögener Schlinge along Donau, halfway between Linz and Passau, alt. $540 \mathrm{~m}$, on Fagus, on P. hypotremella, 4 ix 1996, A. Aptroot 39902 (ABL), F. Berger 10160 (hb. Berger, hb. Diederich) \& G. M. van Herk s.n. (hb. van Herk).-The Netherlands: (all below $100 \mathrm{~m}$ alt.) Friesland: Oldeberkoop, on Quercus robur along Oosterwoldse Weg, on P. hypotremella, 30x 1996, C. M. van Herk 2493-5 (hb. Diederich, hb. van Herk); ibid., on P. oleagina, C. M. van Herk 2493-4 (hb. Diederich, hb. van Herk); Gelderland: Hoevelaken, on Quercus, on P. hypotremella, 5 iv 1991, L. Spier 2302 (hb. Spier).

Sphinctrina anglica (selected specimens). Austria: Osttirol: Hohe Tauern, Glocknergruppe, Dorfertal, alt. $1670 \mathrm{~m}$, on Larix decidua, on P. hypotremella, 6 ix 1990, R. Türk (STU); Virgen, Zedlach, alt. $1600 \mathrm{~m}$, on wood, on $P$. hypotremella, 2 viii $1988, R$. Türk, distributed in Vězda, Lich. sel. exs. no. 2281 (B).-Germany: Baden: Schwarzwald, Lahr, $520 \mathrm{~m}$, on Quercus, on 
TABLE 1. Lichen composition of 95 roadside sample plots with Protoparmelia hypotremella in the Netherlands ${ }^{\star}$

Species

Anaptychia ciliaris

Arthonia spadicea

Bacidia arnoldiana

Buellia griseovirens

B. punctata

Calicium glaucellum

C. viride

Candelaria concolor

Candelariella reflexa

C. vitellina

C. xanthostigma

Chaenotheca chrysocephala

C. ferruginea

Cladonia species

Cliostomum griffithii

Dimerella pineti

Diploicia canescens

Evernia prunastri

Gyalideopsis anastomosans

Haematomma ochroleucum var. porphyrium $\quad 39$

Hypocenomyce scalaris $\quad 19$

Hypogymnia physodes $\quad 35$

H. tubulosa 6

Lecanora aitema

$\begin{array}{lr}\text { L. carpinea } & 19\end{array}$

L. chlarotera $\quad 69$

L. conizaeoides $\quad 32$

L. dispersa 27

L. expallens

L. hageni

L. horiza 13

L. muralis 4

L. pulicaris $\quad 27$

L. saligna

L. symmicta 9

Lecidella elaeochroma $\quad 36$

L. flavosorediata $\quad 12$

L. scabra 2

Lepraria incana $\quad 91$

Micarea nitschkeana 3

Mycoblastus fucatus 1

Ochrolechia androgyna $\quad 32$

O. turneri 1

Opegrapha atra 3

O. vulgata 1

Parmelia acetabulum $\quad 59$

P. caperata 21

P. coniocarpa 2

P. elegantula 16

$\begin{array}{ll}\text { P. exasperatula } & 18\end{array}$ 
TABLE 1. Continued

\begin{tabular}{|c|c|}
\hline Species & Number of plots \\
\hline P. glabratula & 13 \\
\hline$P$. laciniatula & 11 \\
\hline$P$. revoluta & 37 \\
\hline$P$. saxatilis & 17 \\
\hline P. subaurifera & 75 \\
\hline P. subrudecta & 78 \\
\hline P. sulcata & 87 \\
\hline P. tiliacea & 3 \\
\hline Pertusaria albescens & 25 \\
\hline P. amara & 35 \\
\hline P. coccodes & 42 \\
\hline$P \cdot$ pertusa & 32 \\
\hline Phaeophyscia orbicularis & 18 \\
\hline Phlyctis argena & 51 \\
\hline Physcia adscendens & 42 \\
\hline P. caesia & 33 \\
\hline P. dubia & 15 \\
\hline P. tenella & 89 \\
\hline Physconia distorta & 1 \\
\hline P. enteroxantha & 4 \\
\hline$P$. grisea & 9 \\
\hline Placynthiella icmalea & 3 \\
\hline Protoparmelia hypotremella sp. nov. & 95 \\
\hline$P$. oleagina & 22 \\
\hline Pseudevernia furfuracea & 18 \\
\hline Pyrrhospora quernea & 57 \\
\hline Ramalina farinacea & 77 \\
\hline R. fastigiata & 66 \\
\hline R. fraxinea & 2 \\
\hline R. lacera & 2 \\
\hline Schismatomma decolorans & 26 \\
\hline Sphinctrina anglica & 4 \\
\hline Strangospora pinicola & 5 \\
\hline Trapeliopsis granulosa & 1 \\
\hline Tremella wirthii & 1 \\
\hline Usnea species & 2 \\
\hline Xanthoria candelaria & 76 \\
\hline$X$, parietina & 60 \\
\hline$X$. polycarpa & 82 \\
\hline
\end{tabular}

*At each site usually ten Quercus robur trees are investigated. Mean number of species per site $=26$. Data collected by the third author during mapping programme at the request of the Dutch government.

P. hypotremella, 9 viii 1988, V. Wirth 16992 (STU).--The Netherlands: (all below $100 \mathrm{~m}$ alt.) Drenthe: Wezup, on Quercus along road, on P. oleagina, 3 vii 1991, C. M. van Herk 2219-4 (hb. van Herk); Hoogeveen, Noordsche Schut, on Quercus along road, on P. hypotremella, 5 vii 1991, C. M. van Herk 2233-10 (hb. van Herk). Gelderland: Hooglanderveen, on Quercus in wood, on P. hypotremella, 21 iii 1991, L. Spier 2306 (hb. Spier). Utrecht: Leusden, on Quercus along road, on P. hypotremella, 3 xii 1993, C. M. van Herk 4017 (hb. van Herk); Woudenberg, on Quercus along road, on P. oleagina, 16 iii 1994, C. M. van Herk, 4052 (hb. van Herk). 
We are pleased to thank Dr H. Th. Lumbsch for analysis of the chemistry by HPLC, Dr B. J. Coppins for discussions on this species and for arranging the loan from E, Dr F. Berger for leading an excursion to an Austrian locality of $P$. hypotremella, Dr H. J. M. Sipman and Dr L. Tibell for checking the $\mathrm{B}$ and UPS herbarium for additional records and the provincial administrations of Groningen, Friesland, Drenthe, Overijssel, Gelderland, Utrecht and Noord-Brabant for placing the Dutch records and species composition of the sites at our disposal.

\section{REFERENCES}

Brand, A. M., Aptroot, A., Bakker, A. J. de \& Dobben, H. F. van (1988) Standaardlijst van de Nederlandse Korstmossen. Wetenschappelijke Mededeling Koninklijke Nederlandse Natuurhistorische Vereniging 188: 1-68.

Coppins, B. J. (1992) Protoparmelia M. Choisy (1929). In The Lichen Flora of Great Britain and Ireland (Purvis, O. W., Coppins, B. J., Hawksworth, D. L., James, P. W. \& Moore, D. M., eds): 501-505. London: Natural History Museum Publications.

Diederich, P. (1996) The lichenicolous heterobasidiomycetes. Bibliotheca Lichenologica 61 : 1-198.

Herk, C. M. van (1993) Interessante korstmosvondsten op eiken in Noord- en Oost-Nederland. Buxbaumiella 31: 56-66.

Spier, L. \& Herk, C. M. van (1993) Sphinctrina anglica en zijn gastheren. Buxbaumiella 31: 67-68.

Wirth, V. (1985) Zur Ausbreitung, Herkunft und Ökologie anthropogen geförderter Rinden- und Holzflechten. Tuexenia 5: 523-535. 